This item was submitted to Loughborough's Research Repository by the author.

Items in Figshare are protected by copyright, with all rights reserved, unless otherwise indicated.

\title{
Genetic association of pro-inflammatory cytokine gene polymorphisms with coronary artery disease (CAD) in a North Indian population
}

PLEASE CITE THE PUBLISHED VERSION

https://doi.org/10.1016/j.gene.2017.07.050

\section{PUBLISHER}

(C) Elsevier

\section{VERSION}

AM (Accepted Manuscript)

\section{PUBLISHER STATEMENT}

This work is made available according to the conditions of the Creative Commons Attribution-NonCommercialNoDerivatives 4.0 International (CC BY-NC-ND 4.0) licence. Full details of this licence are available at: https://creativecommons.org/licenses/by-nc-nd/4.0/

\section{LICENCE}

CC BY-NC-ND 4.0

\section{REPOSITORY RECORD}

Mastana, Sarabjit S., Swayam Prakash, Elizabeth Claire Akam, Melissa Kirby, Martin R. Lindley, Nakul Sinha, and Suraksha Agrawal. 2019. "Genetic Association of Pro-inflammatory Cytokine Gene Polymorphisms with Coronary Artery Disease (CAD) in a North Indian Population". figshare. https://hdl.handle.net/2134/26000. 
Genetic Association of pro-inflammatory cytokine gene polymorphisms with coronary artery disease (CAD) in a North Indian population

Sarabjit Mastana ${ }^{1}$, Swayam Prakash ${ }^{2}$, Elizabeth C Akam ${ }^{1}$, Melissa Kirby ${ }^{1}$, Martin R Lindley ${ }^{1}$, Nakul Sinha ${ }^{3}$, Suraksha Agrawal ${ }^{3}$

\footnotetext{
${ }^{1}$ Human Genomics Lab, School of Sport, Exercise and Heath Sciences, Loughborough University, Loughborough, Leicestershire, LE11 3TU, United Kingdom.

${ }^{2}$ Department of Hematology, SGPGIMS, Lucknow, India

${ }^{3}$ Department of Cardiology, SGPGIMS, Lucknow, India
}

Key words: TNF- $\alpha$-308 (G/A) (rs1800797), TNF- $\beta+252$ (A/G) (rs909253), IL-6 -174 (G/C) (rs1800795), IL6 -597 (G/A) (rs1800797), and IFN-y +874 (T/A) (rs2430561), CAD, North India.

Corresponding author; Dr Sarabjit Mastana, SSEHS, Loughborough University, Loughborough, Leicestershire, LE11 3TU, United Kingdom: Phone +44 (0)1509 223041: Fax: +44 (0)1509 226301; E mail s.s.mastana@lboro.ac.uk 


\section{Abstract:}

Background: Cytokines regulate the expression of inflammatory molecules which destabilize the atheromatic plaques. This study focuses on studying the association of inflammatory cytokine polymorphisms like TNF- $\alpha-308$ (G/A), TNF- $\beta+252$ (A/G), IL-6 -174 (G/C) and IL-6 -597 (G/A), and IFN- $\gamma+874$ (T/A) with coronary artery disease (CAD) among north Indian patients.

Materials and methods: 143 CAD and 137 normal healthy controls were recruited in this study. DNA extraction was carried out by high salting out method. TNF- $\alpha$-308 (G/A) (rs1800797), TNF- $\beta+252$ (A/G) (rs909253), IL-6 -174 (G/C) (rs1800795), IL6 -597 (G/A) (rs1800797), and IFN-y +874 (T/A) (rs2430561) SNPs were genotyped by TaqMan ${ }^{\circ} S N P$ genotyping assays. Different statistical analyses were performed using SPSS v 22.0 and SNPStats. $\mathrm{p} \leqslant 0.05$ was considered significant.

Results: Significant risk association with CAD was found for TNF- $\alpha-308$ (G/A) "A" allele $(\mathrm{OR}=5.6, \mathrm{CI} 1.8-17.4, \mathrm{p}=0.001)$ and TNF- $\beta+252(\mathrm{~A} / \mathrm{G})$ " $\mathrm{G}$ ” allele (OR=3.4, $\mathrm{CI}=1.9-6.0$, $\mathrm{p}<0.001)$. However, no statistical significance was found for IL-6 -174 (G/C) or IL6 -597 (G/A), with CAD. TNF- $\alpha-308$ (G/A), and TNF- $\beta+252$ (A/G) haplotype “GG” “AG” increased CAD risk significantly (GG haplotype, adjusted OR $=2.6$, CI 1.4-5.0, $p=0.003$ and AG haplotype OR =8.5, CI 2.2-33.35, $\mathrm{p}=0.002$ ) after adjustments for age, sex, TC, TG, HDL, APOB, smoking and diet.

Discussion: The present study found significant risk association for TNF- $\alpha-308$ (G/A), and TNF- $\beta+252(\mathrm{~A} / \mathrm{G})$ genotypes, alleles and haplotypes, with CAD in a North Indian Population. 


\section{Introduction}

Coronary artery disease (CAD) is a major cause of morbidity and mortality globally and has a complex developmental process with a number of contributing factors; gender, age, inflammation, hypertension, hypercholesterolemia, diabetes, obesity, tobacco smoking, alcohol drinking, total cholesterol and LDL cholesterol (Hansson, 2005;Yiannakouris et al., 2014). However, not all individuals who are exposed to the same risk factors of CAD necessarily develop disease, which suggests that inherited genetic factors contribute to the underlying pathogenesis of CAD. Indians are among the populations with the highest susceptibility and have an alarmingly high incidence of CAD (Enas \& Senthilkumar, 2001). In addition to traditional CAD risk factors, strict endogamous marital patterns, rapid urbanisation and decreases in physical activity are some of the additional factors driving rampant increases in CAD among Indian populations. However, even all the risk factors taken together do not fully explain the complexity or the magnitude of disease burden (Anand et al., 2000). Thus genetic factors should be comprehensively and systematically studied in different populations of the Indian Subcontinent.

Inflammation plays a central role in atherosclerosis development and other manifestations of CAD (Hansson, 2005; Zakynthinos and Pappa, 2009). The underlying pathological mechanism of CAD is atheroma plaque instability, which is characterized by chronic inflammation caused by oxidized lipids adherent to the inner layer of the arterial wall. While the molecular mechanisms involved in the pathogenesis of CAD are still being de-convoluted (Libby at al., 2011) there is a consensus that the main events of unstable angina and myocardial infarction are due to the involvement of major inflammatory cytokines.

Cytokines are produced in a variety of tissues and regulate the expression of a number of other inflammatory molecules which can lead to destabilization and finally rupture of vulnerable atheromatic plaques. Several lines of evidence indicate that increased inflammatory cytokine levels and inflammatory cytokine activity detectable in peripheral blood have a prognostic role in predicting future cardiac events and clinical course (Tousoulis et al., 2006; De Gennaro et al., 2012). Recent studies have also shown that inflammationrelated genes might be correlated with CAD risk (Zakynthinos and Pappa, 2009; Shankar and Kakkar 2010; Li et al., 2012; Xie et al., 2012; Singh et al., 2014), thus aligning a number of inflammatory cytokines, their expression and their activity, as key mediators of CAD. Inflammatory pathways are mediated by proximal cytokines, such as Tumor Necrosis FactorAlpha (TNF- $\alpha$ ) and Tumour Necrosis Factor Beta (TNF- $\beta$ )/Lymphotoxin Alpha) (LT- $\alpha$ ), Interferon gamma (IFN-y) and interleukin-6 (IL-6) which suggest they may influence CAD risk. However, multiple pro-inflammatory and anti-inflammatory cytokines may be involved in the pathogenesis of CAD having overlapping, antagonistic and synergistic effects.

Tumor Necrosis Factor- $\alpha(T N F-\alpha)$ and Tumour Necrosis Factor- $\beta$ (TNF- $\beta) / L y m p h o t o x i n$ Alpha) (LT- $\alpha)$

TNF- $\alpha$, is a pleiotropic pro-inflammatory cytokine of 233 amino-acids, which is encoded by TNF- $\alpha$ gene on chromosome $6 \mathrm{p} 21$ falling within the major histocompatibility complex (MHC) 
cluster on chromosome 6. It is generated by activated macrophages and facilitates the recruitment and infiltration of macrophages/monocytes into the sub-endothelium of arteries and contributes to the reduction of lipoprotein lipase activity. Elevated TNF- $\alpha$ levels have consistently been reported in patients with heart failure and increasing concentrations of the cytokine are related to the severity of CAD and mortality rate in patients. Different polymorphisms of the TNF- $\alpha$ gene may also lead to variation in the plasma level of TNF- $\alpha$ as there are several single nucleotide polymorphisms (SNPs) both within the gene and its promoter region. There have been significant susceptible/positive associations reported between TNF- $\alpha-308$ (G/A) locus and CAD however other studies failed to find associations (Banerjee et al 2009; Bhanushali and Das 2013; Elahi et al., 2009; Garg et al., 2013; Wang et al., 2015).

Lymphotoxin-alpha (LTA) also known as TNF beta (TNF- $\beta$ ), is another pro-inflammatory cytokine which plays an important role in the immunologic response. The LTA gene, like the TNF- $\alpha$ gene, is also located within the tumour necrosis factor (TNF) gene cluster in the MHC region on chromosome 6 at position $6 \mathrm{p} 21.3$. TNF- $\beta$ has been linked in a number of studies to the intensity and duration of local inflammation with TNF- $\beta+252(\mathrm{~A} / \mathrm{G})$ correlating with the altered production of TNF- $\beta$ (Messer et al., 1991). In contrast to TNF- $\alpha$ there are only a few studies on the role of TNF- $\beta$ in CAD and the paucity of data is especially limiting on Indian populations (Garg et al., 2013).

\section{Interleukin-6}

Interleukin-6 (IL-6) is another pro inflammatory and immunoregulatory cytokine which has a significant role in the development of CAD. IL-6 up-regulates the synthesis of the acute phase proteins involved in the process of inflammation (Gleeson et al., 2011). IL-6 consists of 184 amino acid residues and is located on chromosome 7 at 7p21-p24. A common G/C polymorphism in the promoter region ( -174 base pairs) affects promoter function and is associated with differences in plasma IL-6 levels (Fishman et al., 1998). While total IL-6 expression may regulate the magnitude of inflammation and its correlation with CAD (Martins et al., 2006; Woo and Humphries, 2013) the IL-6 -174 (G/C) polymorphism has been associated with CAD (meta-analysis, GG vs. CC OR =0.80, CI 0.65-98, p=0.03, Yang et al., 2013). In addition some other polymorphisms in this gene promoter region (-572G/C and $-597 \mathrm{G} / \mathrm{A}$ ) are also predictors of the cytokine concentrations in plasma following inflammatory stimulus. These polymorphisms may influence CAD susceptibility by altering gene regulation and protein expression (Elahi et al., 2009; Woo and Humphries, 2013). Some studies show that IL6 polymorphisms are significantly increase the risk for CAD in different populations, but results are inconsistent and conflicting (Banerjee et al., 2009; Bhanushali and Das, 2013; Cui et al., 2013; Elahi et al., 2009; Mishra et al., 2013; Satti et al., 2013; Hou et al., 2015).

\section{Interferon gamma $(I F N-\gamma)$}

Interferon gamma (IFN- $\gamma$ ) is a pleiotropic soluble cytokine with antiviral and anti-tumour properties and its levels are elevated in unstable angina and myocardial infarction (Pasqui et 
al., 2006). The IFN- $\gamma$ gene is located on chromosome 12q24.1, within this region, a SNP at position +874 (in the $1^{\text {st }}$ intron) of the IFN- $\gamma$ gene (rs2430561) maps to a putative nuclear factor- $\kappa \mathrm{B}(\mathrm{NF}-\kappa \mathrm{B})$ binding site. This polymorphism ( $\mathrm{T}$ allele) correlates with a higher production of IFN- $\gamma$ and is associated with disease severity in different autoimmune and inflammatory diseases (Pacheco et al., 2008, Kohr at al., 2011) an example being the positive association of the $\mathrm{T}$ allele with CAD in an Indian population (OR $=1.53$, CI 1.10-2.13, $\mathrm{p}=0.01$ ) (Garg et al., 2013).

As there are few studies focusing on the role of inflammatory cytokines in CAD specifically in Indian populations (Banerjee et al., 2009; Bhanushali and Das, 2013; Garg et al., 2013; Mishra et al., 2013) this study was designed to explore the roles of TNF- $\alpha-308$ (G/A), TNF- $\beta$ +252 (A/G), IL-6 -174 (G/C) and IL6 -597 (G/A), and IFN-y +874 (T/A) polymorphisms in a North Indian CAD population. This study was designed to contribute to the knowledge of population specific genetic risk factors which might improve prediction of CAD risk in Indian populations.

\section{Study population and Methods}

The study population consisted of 137 healthy controls and 143 patients with clinically diagnosed CAD, from Uttar Pradesh, North India (achieving a Quanto predicted sample size of 130 (http://biostats.usc.edu/Quanto.html) to achieve an odds ratio of 1.75 and statistical power above $80 \%$ using previously determined allele frequencies and odds ratios where available (Banerjee et al., 2009; Bhanushali and Das, 2013; Garg et al., 2013)).

Patients were classified on the basis of at least $50 \%$ or more stenosis in one or more coronary arteries verified through coronary angiography. The healthy controls had no known history of ischemic heart disease, hypertension, diabetes, endocrine or metabolic disorders and were selected after administration of a treadmill exercise test to exclude the possibility of the patients having an underlying CAD (Rai et al., 2012). The DNA samples were collected with full written consent and the study protocol was approved by ethics committees of the SGPGIMS, Lucknow and Loughborough University. All recruitment and analyses followed the principles of Helsinki declaration.

Clinical data was gathered on age, gender, diet (vegetarian vs. non-vegetarian), smokingstatus and lipid profiles (plasma total cholesterol (TC), triglycerides (TG), high density lipoproteins (HDL), low density lipoproteins (LDL), very low density lipoproteins (VLDL) and apolipoprotein B (ApoB). DNA extraction was performed using the salting out method (Sambrook and Russell, 2006) and genotyping of the TNF- $\alpha$-308 (G/A) (rs1800629), TNF- $\beta$ +252 (A/G) (rs909253), IL-6 -174 (G/C) (rs1800795) and IL6 -597 (G/A) (rs1800797) and IFN-y +874 (T/A) (rs2430561) polymorphisms were performed using TaqMan ${ }^{\circledR S N P}$ Genotyping Assays. Genotypes were scored directly by viewing the presence or absence of fluorescence peaks using the StepOne TM Software v.2.3 (Applied Biosystems). Overall genotyping success rates varied from 94\% for IL6 -597 (G/A) (rs1800797) to 99\% for TNF- $\alpha$ -308 (G/A), (rs1800629). Failures were primarily due to DNA storage degradation and 
quality issues with $10 \%$ of the sample randomly repeated to test the reliability of genotyping the results of which indicate $100 \%$ concordance at all SNPs.

Statistical analysis was carried out using the software packages EXCEL (Microsoft ${ }^{\circledR}$ ) and SPSS v 22.0 (SPSS Inc., Chicago, IL, US).). The patient and control databases were both assessed for Hardy-Weinberg Equilibrium (HWE) by calculating a chi-square value.

Association statistics like odds ratios (OR) associated confidence intervals and p values were calculated using online programme SNPSTATs (http://bioinfo.iconcologia.net/SNPstats) (Solé et al., 2006). Clinical and life style parameters were analysed using t-tests and where required Kruskal-Wallis test. A p-value $\leq 0.05$ was considered statistically significant. SNPstats programme was also used for adjustments for various clinical and demographic parameters (age, TC, TG, HDL, LDL, VLDL, APOB) and calculation of linkage disequilibrium and construction of haplotypes.

\section{Results}

\section{Clinical parameters}

In the present sample, a statistically significant difference in Age, TC, TG, LDL, VLDL, and APOB was observed between CAD patients and controls. The patient cohort were older by nearly 4.5 years and as expected patients had higher levels of lipids (Table 1).

\section{Genotype and allele frequency distribution}

The genotype (number, percentage), and allele frequencies (with Standard errors (SE)) of the studied samples were in Hardy Weinberg Equilibrium (HWE) (Table 2). HWE was maintained for all the loci both in patients and controls except IFN- $\gamma+874$ (T/A) in controls $(p=0.001)$ where there was an excess of homozygote genotypes and deficiency of heterozygotes. The crude association analysis showed that at TNF- $\alpha-308$ (G/A) locus, AG genotype (OR =5.3, CI 2.0-14.4, $\mathrm{p}=0.0004)$, and A allele (OR =5.4, CI 2.0-14.5, $\mathrm{p}=0.0001$ ) were significant susceptible contributors to CAD in this population (Table 2). These positive associations became stronger (AG genotype OR $=5.5$ CI 1.7-17.3, $\mathrm{p}=0.005$ and A allele OR =5.6, CI 1.8-17.4, $\mathrm{p}<0.001$ ) when adjusted for age, sex, TC, TG, HDL, APOB, smoking and diet. At this locus, all p values remained significant even after Bonferroni correction.

At TNF- $\beta+252$ (A/G) locus, GG genotype (OR = 4.7, CI 1.5-15.2, $\mathrm{p}<0.0001)$ and $\mathrm{G}$ allele $(\mathrm{OR}=3.1$, CI 2.0-4.9, $\mathrm{p}<0.0001)$ were positively associated with the CAD in this population. After adjusting for age, sex, TC, TG, HDL, APOB, smoking and diet, these odds ratios remained significant and improved in all models (e.g. GG OR $=6.3$, CI 1.5-25.9, $\mathrm{p}<0.0001$ and $\mathrm{G}$ allele $\mathrm{OR}=3.4$, CI 1.9-6.0, $\mathrm{p}<0.0001$ ). All genotypes containing $\mathrm{G}$ allele remained significant following Bonferroni corrections except for the recessive model.

Both IL-6 (IL6 -174 (G/C) and IL6-597 (G/A)) loci showed no statistically significant association with CAD in any model or combination. The IFN- $y+874$ (T/A) locus showed risk association ( $\mathrm{OR}=1.8, \mathrm{CI}=1.0-3.1$ ) at co-dominant (AT vs AA) and over-dominant (AT vs $\mathrm{AA}+\mathrm{TT}$; OR=1.7, $\mathrm{CI}=1.1-2.8$ ) models which became insignificant when adjusted for age, sex, TC, TG, HDL, APOB, smoking and diet. Other genotype combinations and models were 
statistically non-significant. A caution is warranted in interpretation of the results at IFN- $\mathrm{\gamma}$ +874 (T/A) locus as controls showed departure from HWE.

\section{Haplotype frequency}

Haplotype analysis was carried out at TNF- $\alpha-308$ (G/A), TNF- $\beta+252$ (A/G), and IL-6 -174 (G/C) and IL6 -597 (G/A) loci and results are presented in Table 3. TNF- $\alpha$-308 (G/A), TNF$\beta+252(\mathrm{~A} / \mathrm{G})$ haplotypes GG (crude OR =2.5, CI 1.5-4.1, $\mathrm{p}=0.0005$ ) and AG (crude OR = 7.8, CI 2.6-24.0, $\mathrm{p}=0.0003$ ) increased the disease risk significantly even after the adjustments for age, sex, TC, TG, HDL, APOB, smoking and diet (GG haplotype OR =2.6, CI 1.4-5.0, p $=0.003$ and AG haplotype OR = 8.5, CI 2.2-33.4, p =0.002). At the IL6 gene $(\mathrm{IL}-6-174(\mathrm{G} / \mathrm{C})$ and IL6 -597 (G/A)), no haplotype were significantly susceptible or protective.

\section{Interaction of SNPs with conventional CAD risk factors}

One way ANOVAs were carried out for genotypes and clinical parameters in both patients and controls to evaluate the contribution of genotypes to these intermediate phenotypes (Table 4). At TNF- $\alpha-308$ (G/A) and TNF- $\beta+252$ (A/G) loci, there were no significant interactions between genotypes and age or lipid parameters. At other polymorphisms, there were some $\mathrm{p}$ values $<0.05$ before the Bonferroni correction but these become non-significant after correction. The IL-6 -174 (G/C) polymorphism is the only polymorphism showing highest number (3) interactions with TC, HDL, and LDL in control population before correction.

Cross tabulations were carried out for genotypes and categorical variables (gender, diet and smoking habit) to explore interactions. In these analyses none of the results achieved statistical significance either in patients or controls. Contrary to our expectations, none of the inflammatory polymorphisms studied here interacted with smoking habits (results not presented but available).

We also carried out binary logistic regression analysis (results not shown, but available) which confirmed that TNF- $\beta+252$ (A/G), age, two lipids; VLDL and APOB were independent contributors/predictors of CAD in this population.

\section{Discussion}

Genetic polymorphisms have an important role in the regulation of gene expression, and thus gene polymorphisms may contribute to the inter-individual differences in susceptibility, inception, progression and severity of disease. In this study we analysed five single nucleotide polymorphisms (SNPs) in four pro inflammatory genes (TNF- $\alpha$-308 (G/A), TNF$\beta+252$ (A/G), IL-6 -174 (G/C) and IL6 -597 (G/A), and IFN- $\gamma+874$ (T/A)) using sensitive genotyping assays. The allele frequencies observed in controls were comparable to many populations of the Indian subcontinent and online databases (1000 genomes (IGSR); Garg et al., 2013; Mishra et al., 2013).

In our study, TNF- $\alpha-308$ (G/A), promoter region polymorphism was significantly associated with CAD, and this association remained significant in multivariate analysis, even after the 
adjustment with confounding variables (A allele $\mathrm{OR}=5.6$, CI 1.8-17.4, $\mathrm{p}=0.001$ ). Minor allele A was more frequent in patients (9\%) compared to controls (2\%). Previous studies have produced inconsistent results for this locus among Indian populations (Banerjee et al., 2009; Bhanushali and Das 2013; Garg et al., 2013). Bhanushali and Das (2013) did observe a positive association of TNF- $\alpha-308$ (G/A) polymorphism with CAD (OR =3.37, CI 1.0411.54, $\mathrm{p}=0.03$ ), in crude analysis, but it was not significant when confounders were taken into consideration. Garg et al. (2013) analysed an endogamous group from Delhi (India) and showed no significant association of CAD (adjusted OR =1.08, CI 0.94-1.22, NS) with this polymorphism but found it to be associated with BMI. Banerjee and colleagues (2009) also did not find a significant association with CAD and this locus (OR =1.07, CI 0.64-1.81, $\mathrm{p}$ $=0.79$ ). Wang et al. (2015) using a meta-analysis approach showed TNF- $\alpha-308$ (G/A), polymorphism is not associated with CAD in Indian populations (OR $=1.24$, CI 0.86-1.78, $\mathrm{p}=0.26$ ) though there were only a limited number of Indian studies (6) included in this analysis with limited total sample size of 1698 cases and 1459 controls. Further investigations are therefore required to explore the role of this locus in CAD among Indian populations.

TNF- $\beta+252(A / G)$, locus has not been extensively studied with reference to heart disease or CAD in global or Indian populations (Li et al., 2010; Gao et al., 2010; Garg et al., 2013). TNF- $\beta+252$ (A/G) odds ratios in the current CAD samples were highly significant in all models and remain significant after controlling for confounders (age, sex, TC, TG, HDL, APOB, smoking and diet) except in the recessive model. Garg et al. (2013) is the only study available on Indian populations for this locus and our results are consistent with their results though magnitude of effect is nearly 4 times higher in our study (e.g. AG vs. AA ORs 1.14 vs. 4.6). This could be due to sampling of different population groups and geographical position of samples, though patient groups are of similar size. This polymorphism was not associated with CAD in Chinese population or within a large meta-analysis (Gao et al., 2010, Li et al., 2010). As there are not many studies from India, it would be interesting to explore further if this is a regional/population specific disease effect.

Haplotype analysis of TNF- $\alpha-308$ (G/A) and TNF- $\beta+252$ (A/G) (LTA) (Table 3) confirmed that carrying the risk haplotype ' $A G$ ' increases the CAD by nearly 8 fold and this remains significant even controlling for all other clinical variables. As control frequency for this haplotype is relatively low (0.014 compared to patients 0.093 ) caution is warranted in interpretations.

Both IL-6 polymorphisms, (IL-6 -174 (G/C) (rs1800795) and IL-6 -597 (G/A), (rs1800797)) showed no significant associations with CAD in this sample. Overall allele frequencies are comparable with previous studies from the region. Some previous studies looking at different ethnic/regional groups of India have also failed to document association between IL-6 -174 (G/C) (rs1800795) and CAD (Banerjee et al., 2009; Bhanushali and Das 2013). Hou et al. (2015) conducted a meta-analysis with 42 studies including 15,145 cases and 21,496 controls, and they reported that $\mathrm{C}$ allele of IL-6 -174 (G/C) was correlated with an increased risk of CAD in Caucasians (OR=1.12, CI 1.03-1.22, $\mathrm{p}=0.007)$ but a similar effect was not observed in Indian populations $(\mathrm{OR}=1.21$, CI 0.74-1.99, $\mathrm{p}=0.45)$. There are some studies showing the opposite effect, with Phulukdaree et al. (2013) reporting that the presence of the IL-6 -174 
(G/C) C allele influences levels of IL6 and increases the risk of CAD in South African Indians. Elsaid et al. (2014) reported that the G allele of IL-6 -174 (G/C) is significantly associated with CAD (OR = 3.44, CI 2.26-5.23, $\mathrm{p}<0.0001)$ while a recent meta-analysis showed that the association between CAD and IL-6 -174 (G/C) polymorphism is only a mild one (OR $=0.80$, CI 0.65-0.98, $\mathrm{p}=0.034$ ) (Yang et al., 2013).

In case of IL-6 -597 (G/A) (rs1800797), no statistically significant genotypic or allelic association was observed in the present study. There are only limited studies on this locus with reference to CAD in literature and none on Indian populations. Sun et al (2014) also finding no significant association of this locus with CAD in a Chinese population. Overall control allele and genotype frequencies observed here are comparable to a large study on this locus (albeit different disease: leprosy) (Aggarwal et al 2011) but our results are significantly different from a diabetes study which reported a very high frequency of A allele (87\%) in controls (Saxena et al 2014). Haplotype analysis of the two loci also did not reach statistical significance in any combination. Further large scale investigations are required to clarify the possible role of IL-6 polymorphisms in CAD among Indian populations.

IFN- $\mathrm{y}+874$ (T/A) locus is also not studied extensively within Indian populations (Garg et al 2013). Overall our results are comparable with the Garg et al. (2013) study however we only observed Codominant and Overdominant models to be statistically significant and this significance was lost when adjustments were made for clinical parameters. This polymorphism significantly interacted with Age in patients, TG and VLDL in controls in one way ANOVA (Table 4).

There are some limitations to our study which should be considered. Firstly CAD patients and control subjects were recruited from only one hospital leading to some selection bias. However, the genotype distributions for controls of all loci except IFN- $\gamma+874$ (T/A) are in HWE, which gives confidence that it could be considered as being representative of the general population. The relatively small sample size of our study may have limited the statistical power to find the association of these five polymorphisms in CAD risk. However, prior sample size calculations suggested a sample size of 130 patients and 130 controls was sufficient to achieve a large odds ratio of 1.75 and above with $80 \%$ power.

Overall the results provided here show that polymorphisms in TNF- $\alpha-308$ (G/A) and TNF- $\beta$ +252 (A/G) loci enhance the risk of heart disease in a North Indian population. These polymorphisms along with IFN- $y+874$ (T/A) should be analysed in other Indian populations to confirm their role in CAD and other cardio metabolic diseases.

Acknowledgements

Authors acknowledge the financial support from Loughborough University and the Society for the Study of Human Biology (SSHB) (Undergraduate bursary award to M. Kirby). We also thank all our participants, without their participation this research would not have been possible. 
References

Aggarwal S, Ali S, Chopra R, Srivastava A, Kalaiarasan P, Malhotra D, Gochhait S, Garg VK, Bhattacharya SN, Bamezai RN. Genetic variations and interactions in anti-inflammatory cytokine pathway genes in the outcome of leprosy: a study conducted on a MassARRAY platform. J Infect Dis. 2011 Oct 15;204(8):1264-73. doi: 10.1093/infdis/jir516.

Anand SS, Yusuf S, Vuksan V, Devanesen S, Teo KK, Montague PA, Kelemen L, Yi C, Lonn E, Gerstein H, Hegele RA, McQueen M. Differences in risk factors, atherosclerosis, and cardiovascular disease between ethnic groups in Canada: the Study of Health Assessment and Risk in Ethnic groups (SHARE) Lancet. 2000 Jul 22;356(9226):279-84.

Banerjee I, Pandey U, Hasan OM, Parihar R, Tripathi V, Ganesh S. Association between inflammatory gene polymorphisms and coronary artery disease in an Indian population. $\mathrm{J}$ Thromb Thrombolysis. 2009 Jan;27(1):88-94. doi:10.1007/s11239-007-0184-8

Bhanushali AA, Das BR.Promoter variants in interleukin-6 and tumor necrosis factor alpha and risk of coronary artery disease in a population from Western India. Indian J Hum Genet. 2013 Oct;19(4):430-6. doi: 10.4103/0971-6866.124371.

Cui Y, Zheng L, Jiang M, Jia R, Zhang X, Quan Q, Du G, Shen D, Zhao X, Sun W, Xu H, Huang L. Circulating microparticles in patients with coronary heart disease and its correlation with interleukin-6 and C-reactive protein. Mol Biol Rep. 2013 Nov;40(11):6437-42. doi: 10.1007/s11033-013-2758-1

De Gennaro L, Brunetti ND, Montrone D, De Rosa F, Cuculo A, Di Biase M. Subacute inflammatory activation in subjects with acute coronary syndrome and left ventricular dysfunction. Inflammation. 2012 Feb;35(1):363-70. doi: 10.1007/s10753-011-9326-4.

Elahi MM, Asotra K, Matata BM, Mastana SS. Tumor necrosis factor alpha -308 gene locus promoter polymorphism: an analysis of association with health and disease. Biochim Biophys Acta. 2009 Mar;1792(3):163-72.

Elsaid A, Abdel-Aziz AF, Elmougy R, Elwaseef AM. Association of polymorphisms G(174)C in IL-6 gene and G(-1082)A in IL-10 gene with traditional cardiovascular risk factors in patients with coronary artery disease. Indian J Biochem Biophys. 2014 Aug;51(4):282-92.

Enas EA, Senthilkumar A, Juturu V, Gupta R. Coronary artery disease in women. Indian Heart J. 2001 May-Jun;53(3):282-92.

Fishman D, Faulds G, Jeffery R, Mohamed-Ali V, Yudkin JS, Humphries S, Woo P.The effect of novel polymorphisms in the interleukin-6 (IL-6) gene on IL-6 transcription and plasma IL-6 levels, and an association with systemic-onset juvenile chronic arthritis. J Clin Invest. 1998 Oct 1;102(7):1369-76. doi: 10.1172/JCI2629

Gao H, Zhang Z, Zhang J, Zhao N, Li Q, Bai M.Association of LT-alpha Ala252Gly gene polymorphism and the genetic predisposition of coronary heart disease in Chinese. Mol Biol Rep. 2010 Jan;37(1):47-50. doi: 10.1007/s11033-009-9509-3. 
Garg PR, Saraswathy KN, Kalla AK, Sinha E, Ghosh PK.Pro-inflammatory cytokine gene polymorphisms and threat for coronary heart disease in a North Indian Agrawal population. Gene. 2013 Feb 1;514(1):69-74. doi: 10.1016/j.gene.2012.10.011.

Gleeson MI, Bishop NC, Stensel DJ, Lindley MR, Mastana SS, Nimmo MA.The antiinflammatory effects of exercise: mechanisms and implications for the prevention and treatment of disease. Nat Rev Immunol. 2011 Aug 5;11(9):607-15. doi: 10.1038/nri3041.

Hansson, G. K. Inflammation, Atherosclerosis, and Coronary Artery Disease. N Engl J Med 2005 April ; 352:1685-1695

Hou H, Wang C, Sun F, Zhao L, Dun A, Sun Z. Association of interleukin-6 gene polymorphism with coronary artery disease: an updated systematic review and cumulative meta-analysis. Inflamm Res. 2015 Sep;64(9):707-20. doi: 10.1007/s00011-015-0850-9.

IGSR: The International Genome Sample Resource http://www.internationalgenome.org/

Khor B, Gardet B, Xavier RJ. Genetics and pathogenesis of inflammatory bowel disease. Nature. 2011 June 474, 307-317. doi: 10.1038/nature10209.

Li C, Guo R, Lou J, Zhou H. The transcription levels of ABCA1, ABCG1 and SR-BI are negatively associated with plasma CRP in Chinese populations with various risk factors for atherosclerosis. Inflammation. 2012 Oct;35(5):1641-8. doi: 10.1007/s10753-012-9479-9.

Li W, Xu J, Wang X, Chen J, Zhang C, Sun K, Hui R.Lack of association between lymphotoxin-alpha, galectin-2 polymorphisms and coronary artery disease: a meta-analysis. Atherosclerosis. 2010 Feb;208(2):433-6. doi: 10.1016/j.atherosclerosis.2009.08.014.

Libby P, Ridker PM, Hansson GK. Progress and challenges in translating the biology of atherosclerosis. Nature 2011 May; 473, 317-325 . doi:10.1038/nature10146

Martins IJ, Hone E, Foster JK, Sünram-Lea SI, Gnjec A, Fuller SJ, Nolan D, Gandy SE, Martins RN. Apolipoprotein E, cholesterol metabolism, diabetes, and the convergence of risk factors for Alzheimer's disease and cardiovascular disease. Mol Psychiatry. 2006 Aug;11(8):721-36. doi:10.1038/sj.mp.4001854

Messer G, Spengler U, Jung MC, Honold G, Blömer K, Pape GR, Riethmüller G, Weiss EH. Polymorphic structure of the tumor necrosis factor (TNF) locus: an NCoI polymorphism in the first intron of the human TNF- $\beta$ gene correlates with a variant amino acid in position 26 and a reduced level of TNF- $\beta$ production. J. Exp. Med. 1991 Jan.173 (1): pp. 209-219. doi: 10.1084/jem.173.1.209

Mishra A, Srivastava A, Mittal T, Garg N, Mittal B. Role of inflammatory gene polymorphisms in left ventricular dysfunction (LVD) susceptibility in coronary artery disease (CAD) patients. Cytokine. 2013 Mar;61(3):856-61. doi: 10.1016/j.cyto.2012.12.020 
Pacheco AG, Cardoso CC, Moraes MO, IFNG +874T/A, IL10 -1082G/A and TNF -308G/A polymorphisms in association with tuberculosis susceptibility: a meta-analysis study. Human Genetics. 2008 June 123 (5) 477-484. 008- doi: 10.1007/s00439-0497-5

Pasqui AL, Di Renzo M, Bova G, Maffei S, Pompella G, Auteri A, Puccetti L. Proinflammatory/anti-inflammatory cytokine imbalance in acute coronary syndromes. Clin Exp Med. 2006 Mar;6(1):38-44. doi:10.1007/s10238-006-0092-9

Phulukdaree A, Khan S, Ramkaran P, Govender R, Moodley D, Chuturgoon AA. The interleukin-6 -147 g/c polymorphism is associated with increased risk of coronary artery disease in young South African Indian men. Metab Syndr Relat Disord. 2013 Jun;11(3):205-9. doi: 10.1089/met.2012.0130.

Rai H, Fitt J, Sharma AK, Sinha N, Kumar S, Pandey CM, Agrawal S, Mastana S. Lack of association between Glu298Asp polymorphism and coronary artery disease in North Indians. Mol Biol Rep. 2012 May;39(5):5995-6000. doi: 10.1007/s11033-011-1412-z. Epub 2011 Dec 30.

Sambrook J, Russell DW. Purification of nucleic acids by extraction with phenol:chloroform. CSH Protoc. 2006 Jun 1;2006(1).

Satti HS, Hussain S, Javed Q. Association of interleukin-6 gene promoter polymorphism with coronary artery disease in Pakistani families. ScientificWorldJournal. 2013 Dec 2;2013:538365. doi: 10.1155/2013/538365.

Saxena M, Agrawal CG, Srivastava N, Banerjee M. Interleukin-6 (IL-6)-597 A/G (rs1800797) \& -174 G/C (rs1800795) gene polymorphisms in type 2 diabetes. Indian J Med Res 2014; July, 140: 60-68.

Shanker J1, Kakkar VV. Implications of genetic polymorphisms in inflammation-induced atherosclerosis. Open Cardiovasc Med J. 2010;4:30-7. doi: 10.2174/1874192401004020030. Epub 2010 Feb 23.

Singh P, Singh M, Nagpal HS, Kaur T, Khullar S, Kaur G, Dhillon H, Di Napoli M, Mastana S. A novel haplotype within C-reactive protein gene influences CRP levels and coronary heart disease risk in Northwest Indians. Mol Biol Rep. 2014 Sep;41(9):5851-62. doi: 10.1007/s11033-014-3459-0.

Solé X1, Guinó E, Valls J, Iniesta R, Moreno V.SNPStats: a web tool for the analysis of association studies. Bioinformatics. 2006 Aug 1;22(15):1928-9. Epub 2006 May 23.

Sun GQ, Wu GD, Meng Y, Du B, Li YB. IL-6 gene promoter polymorphisms and risk of coronary artery disease in a Chinese population. Genet Mol Res. 2014 Sep 26;13(3):7718-24. doi: 10.4238/2014.September.26.9.

Tousoulis D, Antoniades C, Koumallos N, Stefanadis C. Pro-inflammatory cytokines in acute coronary syndromes: from bench to bedside. Cytokine Growth Factor Rev. 2006 Aug;17(4):225-33. doi: 10.1016/j.cytogfr.2006.04.003 
Wang J, He Y, Yang Y, Song T, Chen N, Zhou Y.Association between the TNF- $\alpha$ G-308A polymorphism and risk of ischemic heart disease: a meta-analysis. Int J Clin Exp Med. 2015 Jun 15;8(6):8880-92.

Woo P, Humphries SE. IL-6 polymorphisms: a useful genetic tool for inflammation research? J Clin Invest. 2013 Apr;123(4):1413-4. doi: 10.1172/JCI67221. Epub 2013 Apr 1.

Xie X., Ma YT., Yang YN, et al. (2010) Polymorphisms in the SAA1/2 gene are associated with carotid intima media thickness in healthy Han Chinese subjects: the Cardiovascular Risk Survey. PLoS One 5:e13997

Yang Y, Zhang F, Skrip L, Lei H, Wang Y, Hu D, Ding R. IL-6 gene polymorphisms and CAD risk: a meta-analysis. Mol Biol Rep. 2013 Mar;40(3):2589-98. doi: 10.1007/s11033012-2345-X.

Yiannakouris N, Katsoulis M, Trichopoulou A, Ordovas JM, Trichopoulos D. Additive influence of genetic predisposition and conventional risk factors in the incidence of coronary heart disease: a population-based study in Greece. BMJ Open. 2014 Feb 5;4(2):e004387. doi: 10.1136/bmjopen-2013-004387.

Zakynthinos E, Pappa N. Inflammatory biomarkers in coronary artery disease. J Cardiol. 2009 Jun;53(3):317-33. doi:10.1016/j.jjcc.2008.12.007 
Table 1: Baseline characteristics of CAD patients and controls

\begin{tabular}{|c|c|c|c|c|}
\hline Variable & $\begin{array}{l}\text { CONTROL } \\
(\mathrm{n}=137), \\
\text { Mean } \pm \text { SD } \\
\text { Or ( } \mathrm{n} \text {, and \% } \\
\text { for categorical } \\
\text { variables) }\end{array}$ & $\begin{array}{l}\text { PATIENTS } \\
(\mathrm{n}=144) \\
\text { Mean } \pm \text { SD Or (n } \\
\text { and \% for } \\
\text { categorical } \\
\text { variables) }\end{array}$ & $\begin{array}{l}\text { T-test/ } \\
\text { Chi-Square Test }\end{array}$ & $\mathrm{P}$ value \\
\hline Age & $45.02 \pm 14.46$ & $49.51 \pm 11.06$ & -2.910 & $0.004^{*}$ \\
\hline $\begin{array}{l}\text { Sex, } \\
\text { Male: } \\
\text { Female }\end{array}$ & $\begin{array}{l}111(81 \%) \\
26(19 \%)\end{array}$ & $\begin{array}{l}125(87 \%) \\
19(13 \%)\end{array}$ & 1.75 (1df) & 0.186 \\
\hline $\begin{array}{l}\text { Diet } \\
\text { Veg: } \\
\text { Non Veg }\end{array}$ & $\begin{array}{l}65(47 \%): \\
72(53 \%)\end{array}$ & $\begin{array}{l}60(42 \%) \\
84(58 \%)\end{array}$ & 0.95 (1df) & 0.330 \\
\hline $\begin{array}{l}\text { Smoking } \\
\text { Non-smoker } \\
\text { Smoker }\end{array}$ & $\begin{array}{l}61(44 \%) \\
76(56 \%)\end{array}$ & $\begin{array}{l}49(34 \%) \\
95(66 \%)\end{array}$ & 3.25 (1df) & 0.072 \\
\hline TC & $132.76 \pm 34.38$ & $182.32 \pm 106.03$ & -5.322 & $<0.001^{*}$ \\
\hline TG & $145.64 \pm 66.03$ & $208.01 \pm 109.45$ & -5.816 & $<0.001^{*}$ \\
\hline HDL & $23.40 \pm 7.29$ & $29.74 \pm 12.37$ & -5.261 & $<0.001^{*}$ \\
\hline LDL & $80.71 \pm 27.25$ & $106.37 \pm 42.94$ & -5.934 & $<0.001^{*}$ \\
\hline VLDL & $30.08 \pm 13.46$ & $42.79 \pm 18.04$ & -6.61 & $<0.001^{*}$ \\
\hline APOB & $108.76 \pm 45.784$ & $153.50 \pm 43.46$ & -8.394 & $<0.001^{*}$ \\
\hline
\end{tabular}

* =Statistically significant at 5\% level. 
Table 2: Genotype, allele frequencies, Odds ratios and adjustments for various models for the studied SNPs among CAD patients

\begin{tabular}{|c|c|c|c|c|c|c|c|}
\hline Model & $\begin{array}{l}\text { Genotype/ } \\
\text { Allele }\end{array}$ & $\begin{array}{l}\text { Control No, (\%) } \\
\mathrm{N}=136\end{array}$ & $\begin{array}{l}\text { Patients } \\
\text { No, (\%) } \\
\mathrm{N}=143\end{array}$ & Crude OR & $\mathrm{P}$ value & $\begin{array}{l}\text { Age, Sex, TC, TG, } \\
\text { HDL, VLDL, APOB, } \\
\text { Smoking and Diet } \\
\text { Adjusted OR }\end{array}$ & P value \\
\hline \multicolumn{8}{|l|}{ TNF $\alpha-308$ (G/A), rs1800629 } \\
\hline & GG & $131(96.3)$ & $118(82.5)$ & & & & \\
\hline & AG & $5(3.7)$ & $24(16.7)$ & & & & \\
\hline & AA & $0(0.0)$ & $1(0.8)$ & & & & \\
\hline HWE P value & & 0.82 & 0.79 & & & & \\
\hline \multirow[t]{2}{*}{ Allele frequency } & $* \mathrm{G}$ & $0.98( \pm 0.001)$ & $0.91( \pm 0.02)$ & & & & \\
\hline & $* \mathrm{~A}$ & $0.02( \pm 0.001)$ & $0.09( \pm 0.02)$ & & & & \\
\hline Co-dominant (AG vs. GG) & & & & $5.3(2.0-14.4)$ & $<0.001$ & $5.5(1.7-17.3)$ & 0.005 \\
\hline Co-dominant (AA vs. GG) & & & & NA & & NA & \\
\hline Dominant (AA+AG vs.GG) & & & & $5.5(2.1-15.0)$ & $<0.001$ & $5.7(1.8-17.8)$ & 0.001 \\
\hline Recessive (A/A vs. AG+GG) & & & & NA & & NA & \\
\hline Over-dominant (AG vs. GG+AA) & & & & $5.3(1.9-14.3)$ & $<0.001$ & $5.5(1.7-17.3)$ & 0.002 \\
\hline Log-additive & & & & $5.4(2.0-14.5)$ & $<0.001$ & $5.6(1.8-17.4)$ & 0.001 \\
\hline \multicolumn{8}{|l|}{ TNF $\beta+252$ (A/G), rs909253 } \\
\hline & AA & $107(79.3)$ & $68(48.3)$ & & & & \\
\hline & $\mathrm{AG}$ & $24(17.8)$ & $61(43.2)$ & & & & \\
\hline & GG & $4(2.9)$ & $12(8.5)$ & & & & \\
\hline HWE-P value & & 0.08 & 0.68 & & & & \\
\hline \multirow[t]{2}{*}{ Allele frequency } & $* \mathrm{~A}$ & $0.88( \pm 0.02)$ & $0.70( \pm 0.03)$ & & & & \\
\hline & ${ }^{*} \mathrm{G}$ & $0.12( \pm 0.02)$ & $0.30( \pm 0.03)$ & & & & \\
\hline Co-dominant (AG vs. AA) & & & & $4.0(2.3-7.0)$ & $<0.001$ & $4.6(2.1-9.8)$ & $<0.001$ \\
\hline Co-dominant (GG vs. AA) & & & & $4.7(1.5-15.2)$ & $<0.001$ & $6.3(1.5-25.9)$ & $<0.001$ \\
\hline Dominant (GG+AG vs. AA) & & & & $4.1(2.4-7.1)$ & $<0.001$ & $4.9(2.4-9.9)$ & $<0.001$ \\
\hline Recessive (GG vs. AG+AA) & & & & $3.0(1.0-9.6)$ & 0.05 & $4.3(1.1-17.6)$ & 0.03 \\
\hline Overdominant (AG vs. AA+GG) & & & & $3.5(2.0-6.1)$ & $<0.001$ & $4.0(1.9-8.4)$ & 0.002 \\
\hline Log-additive & & & & $3.1(2.0-4.9)$ & $<0.001$ & $3.4(1.9-6.0)$ & $<0.001$ \\
\hline \multicolumn{8}{|l|}{ IL6 -174 (G/C), rs1800795 } \\
\hline & GG & $91(69.5)$ & $105(76.1)$ & & & & \\
\hline & GC & $39(29.8)$ & $32(23.2)$ & & & & \\
\hline & $\mathrm{CC}$ & $1(0.7)$ & $1(0.7)$ & & & & \\
\hline HWE-P value & & 0.14 & 0.35 & & & & \\
\hline
\end{tabular}




\begin{tabular}{|c|c|c|c|c|c|c|c|}
\hline Allele frequency & ${ }^{*} \mathrm{G}$ & $0.84( \pm 0.02)$ & $0.88( \pm 0.02)$ & & & & \\
\hline & ${ }^{*} \mathrm{C}$ & $0.16( \pm 0.02)$ & $0.12( \pm 0.02)$ & & & & \\
\hline Co-dominant (CG vs. GG) & & & & $0.7(0.4-1.2)$ & 0.5 & $0.5(0.2-1.1)$ & 0.2 \\
\hline Co-dominant (CC vs. GG) & & & & $0.9(0.1-14.1)$ & 0.5 & $0.8(0.1-1$ & 0.2 \\
\hline Dominant (CC+CG vs. GG) & & & & $0.7(0.4-1.2)$ & 0.2 & $0.5(0.3-1.1)$ & 0.1 \\
\hline Recessive (CC vs. CG+GG) & & & & $0.9(0.1-15.3)$ & 1.0 & $1.0(0.1-17.2)$ & 0.1 \\
\hline Overdominant (CG vs. GG+CC) & & & & $0.7(0.4-1.2)$ & 0.2 & $0.5(0.3-1.1)$ & 0.1 \\
\hline Log-additive & & & & $0.7(0.5-1.3)$ & 0.2 & $0.6(0.3-1.1)$ & 0.1 \\
\hline \multicolumn{8}{|l|}{ IL6 -597 (G/A), rs1800797 } \\
\hline & GG & $98(76.6)$ & $104(76.4)$ & & & & \\
\hline & $\mathrm{AG}$ & $29(22.6)$ & $30(22.1)$ & & & & \\
\hline & $\mathrm{AA}$ & $1(0.8)$ & $2(1.5)$ & & & & \\
\hline HWE-P value & & 0.47 & 0.85 & & & & \\
\hline \multirow[t]{2}{*}{ Allele frequency } & $* \mathrm{G}$ & $0.88( \pm 0.02)$ & $0.88( \pm 0.02)$ & & & & \\
\hline & $* \mathrm{~A}$ & $0.12( \pm 0.02)$ & $0.12( \pm 0.02)$ & & & & \\
\hline Co-dominant (AG vs. AA) & & & & $0.5(0.1-6.0)$ & 0.9 & $1.0(0.1-16.7)$ & 1.0 \\
\hline Co-dominant (AA vs. GG) & & & & $0.5(0.1-5.9)$ & 0.9 & $1.0(0.1-16.5)$ & 0.9 \\
\hline Dominant (GG+AG vs. AA) & & & & $0.5(0.1-5.9)$ & 0.6 & $1.02(0.1-16.4)$ & 0.9 \\
\hline Recessive (GG vs. AG+AA) & & & & $0.9(0.6-1.8)$ & 0.9 & $1.0(0.6-1.8)$ & 0.9 \\
\hline Overdominant (AG vs. AA+GG) & & & & $1.0(0.5-1.7)$ & 0.9 & $1.0(0.6-1.8)$ & 0.9 \\
\hline Log-additive & & & & $1.0(0.6-1.6)$ & 0.9 & $1.0(0.6-1.7)$ & 0.9 \\
\hline \multicolumn{8}{|l|}{ IFN $\gamma+874$ (T/A), rs2430561 } \\
\hline & AA & $60(45.8)$ & $49(35.2)$ & & & & \\
\hline & $\mathrm{AT}$ & $44(33.6)$ & $65(46.8)$ & & & & \\
\hline & TT & $27(20.6)$ & $25(18.0)$ & & & & \\
\hline HWE-P value & & $0.001 *$ & 0.63 & & & & \\
\hline \multirow[t]{2}{*}{ Allele frequency } & $* \mathrm{~A}$ & $0.63( \pm 0.03)$ & $0.59( \pm 0.03)$ & & & & \\
\hline & $* \mathrm{~T}$ & $0.37( \pm 0.03)$ & $0.41( \pm 0.03)$ & & & & \\
\hline Co-dominant (AT vs. AA) & & & & $1.8(1.0-3.1)$ & 0.1 & $1.5(0.7-2.9)$ & 0.6 \\
\hline Co-dominant (TT vs. AA) & & & & $1.1(0.6-2.2)$ & 0.1 & $1.06(0.5-2.5)$ & 0.6 \\
\hline Dominant (TT+AT vs. AA) & & & & $1.5(0.9-2.5)$ & 0.1 & $1.30(0.7-2.5)$ & 0.4 \\
\hline Recessive (TT vs. AT+TT) & & & & $0.8(0.5-1.5)$ & 0.6 & $0.9(0.4-1.9)$ & 0.8 \\
\hline Over-dominant (AT vs. AA+TT) & & & & $1.7(1.1-2.8)$ & 0.03 & $1.4(0.7-2.7)$ & 0.3 \\
\hline Log-additive & & & & $1.1(0.8-1.6)$ & 0.4 & $1.1(0.7-1.6)$ & 0.7 \\
\hline
\end{tabular}


Table 3: Haplotype analysis of TNF- $\alpha$ (-308 A/G), TNF- $\beta$ (+252 A/G) and IL-6 (-174 G/C; -597 G/A) polymorphisms

\begin{tabular}{|c|c|c|c|c|c|c|c|}
\hline Haplotype & $\begin{array}{l}\text { Overall } \\
\text { Frequency }\end{array}$ & $\begin{array}{l}\text { Control } \\
\text { Frequency }\end{array}$ & $\begin{array}{l}\text { Patients } \\
\text { Frequency }\end{array}$ & Crude OR & $P$ value & $\begin{array}{l}\text { Age, Sex, TC, TG, HDL, } \\
\text { VLDL, APOB, Smoking } \\
\text { and Diet Adjusted OR }\end{array}$ & $\mathrm{P}$ value \\
\hline \multicolumn{8}{|l|}{ TNF- $\alpha(-308$ A/G) - TNF- $\beta(+252$ A/G) } \\
\hline GA & 0.782 & 0.878 & 0.697 & 1.0 (ref) & & 1.0 (ref) & \\
\hline GG & 0.159 & 0.104 & 0.212 & $2.5(1.5-4.1)$ & $<0.001$ & $2.6(1.4-5.0)$ & 0.003 \\
\hline AG & 0.053 & 0.014 & 0.093 & $7.8(2.6-24.0)$ & $<0.001$ & $8.5(2.2-33.35)$ & 0.002 \\
\hline AA & 0.002 & 0.004 & 0.000 & NA & & NA & \\
\hline Global Haplotype association P value & & & & & $<0.001$ & & $<0.001$ \\
\hline $\mathrm{D}^{\prime}$ & 0.95 & & & & & & \\
\hline $\mathrm{r}$ & 0.45 & & & & & & \\
\hline P value & $<0.001$ & & & & & & \\
\hline \multicolumn{8}{|l|}{ IL-6 -174 (G/C) - IL-6 -597 (G/A ) } \\
\hline GG & 0.849 & 0.847 & 0.851 & 1.0 (ref) & & 1.0 (ref) & \\
\hline CA & 0.113 & 0.121 & 0.105 & $0.8(0.5-1.4)$ & 0.4 & $0.7(0.3-1.3)$ & 0.3 \\
\hline CG & 0.026 & 0.032 & 0.020 & $0.6(0.2-1.9)$ & 0.4 & $0.7(0.2-2.9)$ & 0.6 \\
\hline GA & 0.012 & 0.0 & 0.024 & NA & & NA & \\
\hline Global Haplotype association P value & & & & & 0.02 & & 0.26 \\
\hline $\mathrm{D}^{\prime}$ & 0.89 & & & & & & \\
\hline $\mathrm{r}$ & 0.83 & & & & & & \\
\hline$P$ value & $<0.001$ & & & & & & \\
\hline
\end{tabular}


Table 4: One Way ANOVA tests for interaction of genotypes with conventional risk factors

\begin{tabular}{|c|c|c|c|c|c|c|c|c|c|c|c|c|}
\hline & \multirow[t]{2}{*}{ Mean+SD } & \multirow[t]{2}{*}{ Mean+SD } & \multicolumn{10}{|l|}{ P-value } \\
\hline & & & \multicolumn{2}{|c|}{ TNF- $\alpha(-308$ G/A) } & \multicolumn{2}{|c|}{ TNF- $\beta$ (+252 A/G) } & \multicolumn{2}{|c|}{ IFN- $\gamma(+874$ T/A) } & \multicolumn{2}{|c|}{ IL-6 (-174 G/C) } & \multicolumn{2}{|c|}{ IL-6 (-597G/A) } \\
\hline & Patients & Controls & Patients & Controls & Patients & Controls & Patients & Controls & Patients & Controls & Patients & Controls \\
\hline Age & $49.51 \pm 11.06$ & $45.02 \pm 14.46$ & 0.68 & 0.37 & 0.65 & 0.17 & $0.01 *$ & 0.84 & 0.40 & 0.21 & 0.41 & 0.17 \\
\hline TC & $182.32 \pm 106.03$ & $132.76 \pm 34.38$ & 0.65 & 0.25 & 0.86 & 0.08 & 0.56 & 0.48 & 0.21 & $0.02 *$ & 0.28 & $0.02 *$ \\
\hline TG & $208.01 \pm 109.45$ & $145.64 \pm 66.03$ & 0.79 & 0.41 & 0.99 & 0.42 & 0.79 & $0.02 *$ & 0.46 & 0.78 & 0.14 & 0.74 \\
\hline HDL & $29.74 \pm 12.37$ & $23.40 \pm 7.29$ & 0.71 & 0.33 & 0.14 & 0.16 & 0.74 & 0.49 & 0.18 & $0.05^{*}$ & 0.25 & 0.04 \\
\hline LDL & $106.37 \pm 42.94$ & $80.71 \pm 27.25$ & 0.56 & 0.23 & 0.37 & 0.16 & 0.14 & 0.91 & 0.69 & $0.02 *$ & 0.95 & 0.02 \\
\hline VLDL & $42.79 \pm 18.04$ & $30.08 \pm 13.46$ & 0.12 & 0.12 & 0.46 & 0.83 & 0.24 & $0.05^{*}$ & 0.10 & 0.94 & $0.01^{*}$ & 0.94 \\
\hline APOB & $153.50 \pm 43.46$ & $108.76 \pm 45.78$ & 0.67 & 0.67 & 0.91 & 0.97 & 0.92 & 0.70 & 0.97 & 0.09 & 0.41 & 0.05 \\
\hline & & & & & & & $\begin{array}{l}\text { Post Hoc } \\
\text { tests } \\
\text { Age: TT } \\
\text { vs. AT } \\
=0.03 \\
\text { And AT } \\
\text { vs AA } \\
=0.04\end{array}$ & $\begin{array}{l}\text { Post Hoc } \\
\text { tests } \\
\text { TG: TT } \\
\text { vs. AT } \\
=0.047 \\
\text { And TT } \\
\text { vs. AA } \\
=0.024 . \\
\text { VLDL: } \\
\text { TT vs. } \\
\text { AA }=0.04\end{array}$ & & & & \\
\hline
\end{tabular}

$*=$ Statistically significant at $5 \%$ level 